(c) American Dairy Science Association, 2004.

\title{
Prediction of Fermentation Parameters in Grass and Corn Silage by Near Infrared Spectroscopy
}

\author{
L. K. Sørensen \\ Steins Laboratorium, Ladelundvej 85, 6650 Brørup, Denmark
}

\begin{abstract}
Prediction models were developed for determination of lactic acid (Lac), acetic acid (HAc), $\mathrm{pH}, \mathrm{NH}_{3} \mathrm{~N}$, and ethanol $(\mathrm{EtOH})$ in grass and corn silages by near infrared (NIR) spectroscopy. Generally, Lac, $\mathrm{pH}$, and $\mathrm{NH}_{3}$ $\mathrm{N}$ concentrations in original sample material could be determined with a better accuracy when NIR measurements were performed on dried material rather than on wet material. The difference could only partly be explained by the repeatability error of NIR measurements for compounds stable with respect to drying. The HAc concentration was determined slightly more accurately when measurements were performed on wet material. The respective ratios between analytical concentration range expressed as standard deviation and the root mean square error of cross validation (RMSECV) were 4.9, 2.0, 3.7, and 3.1 for Lac, $\mathrm{HAc}, \mathrm{pH}$, and $\mathrm{NH}_{3}$ $\mathrm{N}$ measured on dried grass silage, and 3.3 for $\mathrm{EtOH}$ measured on wet grass silage. The corresponding standard deviation:RMSECV for corn silage were 4.7, 1.9, $2.4,2.9$, and 4.0. The content of Lac was affected only slightly by drying at $80^{\circ} \mathrm{C}$, whereas the effects on $\mathrm{NH}_{3}$ $\mathrm{N}$ and HAc were more pronounced, depending on silage type.
\end{abstract}

(Key words: fermentation parameter, silage, near infrared spectroscopy)

Abbreviation key: $\mathbf{E t O H}=$ ethanol, HAc $=$ acetic acid, Lac $=$ lactic acid, $\mathbf{N A D H}=$ reduced NAD, $\mathbf{N I R}=$ near infrared, RMSECV = root mean square error of cross validation, RMSEP = root mean square error of prediction, $\mathbf{S D}_{\mathbf{r}, \mathbf{N I R}}=$ standard deviation of NIR measurements repeatability, SEP = standard error of prediction.

\section{INTRODUCTION}

The $\mathrm{pH}$ and the contents of lactic acid (Lac), VFA, $\mathrm{NH}_{3} \mathrm{~N}$, and ethanol (EtOH) in silage are quality parameters affecting feed intake, milk production, and milk

Received March 16, 2004.

Accepted June 9, 2004.

E-mail: lks@steins.dk. flavor. During the fermentation process, sugars are converted mainly to Lac and acetic acid (HAc). To obtain a stable silage with a low content of spore-forming clostridia, Lac production must be sufficiently high to ensure a relatively low $\mathrm{pH}$. The growth of clostridia may otherwise increase the spore level in silage and, from direct and indirect contact contamination of milk, result in cheese spoilage because of uncontrollable gas production and off-flavor from butyric acid production. Apart from Lac, the fermentation process also results in production of VFA including HAc. Some studies indicate that feed intake may be reduced if the concentration of HAc becomes too high (Rook and Gill, 1990). However, the mechanism seems complex because the effect was not observed in other studies (Steen et al., 1998). If the fermentation process proceeds too slowly or is insufficient, an increased portion of the protein may be degraded by microbial activity, resulting in an increased level of $\mathrm{NH}_{3} \mathrm{~N}$. The concentration of $\mathrm{NH}_{3} \mathrm{~N}$ may be a marker parameter for substances reducing feed intake (Rook and Gill, 1990; Steen et al., 1998). The EtOH concentration in silage is normally low, but, in some cases, it can be considerable. This may induce off-flavor in milk (Randby et al., 1998).

Because of the adverse effects of a nonoptimal ensiling process, a rapid and inexpensive analytical method is needed for estimation of silage quality. Near infrared (NIR) spectroscopy has been used successfully for many years in the determination of major chemical constituents and digestibility of forage. However, the possibility of rapid analysis of fermentation parameters by NIR spectroscopy has not been investigated to the same extent. Results on fermentation parameters obtained by calibration on wet material have been reported for grass silage (Snyman and Joubert, 1992; Sinnaeve et al., 1994; Park et al., 1998, 1999, 2002) and for alfalfa and corn silages (Reeves et al., 1989). Measurements on wet material rather than dried material permit very rapid analyses in general and introduce the possibility of analyzing volatile and especially non-ionic volatile compounds. However, practical experience has shown that it may be difficult to obtain the same prediction accuracy on the main constituents. The laboratory savings obtained by excluding the drying and grinding process 
Table 1. Composition of grass silage samples used for calibration as determined by reference methods.

\begin{tabular}{|c|c|c|c|c|c|c|c|c|c|c|}
\hline \multirow[b]{3}{*}{ Analyte } & \multicolumn{6}{|c|}{ Number of samples ${ }^{1}$} & \multirow{2}{*}{\multicolumn{4}{|c|}{ Sample composition }} \\
\hline & & DK & DK & $\mathrm{S}$ & DK & & & & & \\
\hline & Total & 2000 & 2001 & 2001 & 2002 & 2003 & Mean & Minimum & Maximum & $\mathrm{SD}$ \\
\hline DM, \% & 392 & 119 & 140 & 89 & 21 & 23 & 40 & 22 & 79 & 14 \\
\hline $\mathrm{NH}_{3} \mathrm{~N}(\mathrm{DM}),{ }^{2} \%$ & 257 & 0 & 144 & 69 & 21 & 23 & 0.22 & 0.04 & 0.42 & 0.07 \\
\hline $\operatorname{Lac}(\mathrm{DM}),{ }^{2} \%$ & 365 & 119 & 142 & 60 & 21 & 23 & 7.8 & 0.08 & 16 & 3.5 \\
\hline $\mathrm{HAc}(\mathrm{DM}),{ }^{2} \%$ & 271 & 0 & 149 & 78 & 21 & 23 & 2.7 & 0.02 & 12 & 1.9 \\
\hline $\mathrm{pH}$ & 379 & 119 & 145 & 71 & 21 & 23 & 4.3 & 3.7 & 6.4 & 0.41 \\
\hline $\mathrm{EtOH}(\mathrm{DM}),{ }^{2} \%$ & 279 & 0 & 146 & 89 & 21 & 23 & 0.63 & 0.06 & 5.8 & 0.72 \\
\hline $\mathrm{CP}(\mathrm{DM}),{ }^{3} \%$ & 215 & 0 & 140 & 75 & 0 & 0 & 16 & 0.4 & 24 & 2.8 \\
\hline
\end{tabular}

may also be neutralized by the introduction of other disadvantages, such as extended requirements regarding storage conditions, special sample pretreatments, difficulties in automation of the measuring process, and difficulties in subsampling for rational determination of other substances, e.g., elements by atomic spectrometry.

This study investigated the feasibility of analyzing $\mathrm{pH}$, Lac, HAc, $\mathrm{NH}_{3} \mathrm{~N}$, and $\mathrm{EtOH}$ in grass and corn silage by NIR spectroscopy and compared techniques based on dried and wet material analysis.

\section{MATERIALS AND METHODS}

Samples of grass and corn silage were obtained from all regions of Denmark and southern Sweden during the period from 2000 to 2003 . The samples from 2000 and 2001 were used solely for calibration (Tables 1 and 2). The samples from 2002 and 2003 were all from Denmark and were randomly split up into a calibration set (Tables 1 and 2) and a validation set (Tables 3 and 4). The samples from 2000 and 2001 included selected samples of good and poor qualities as estimated by sensoric assessments. The samples from 2002 and 2003 were taken randomly from an annual pool of 15,000 laboratory samples received during the high seasons from August to November.

The samples were equilibrated to room temperature (20 to $24^{\circ} \mathrm{C}$ ) and carefully mixed before NIR measurement. A subsample was packed into a Natural Product Cell (Foss, Hillerød, Denmark) and measured on a NIRSystems 6500 instrument equipped with a transport module (Foss). Reflectance measurements were performed in the wavelength range from 400 to $2500 \mathrm{~nm}$. Two replicate measurements, including repacking of the sample cell, were performed on each sample.

After NIR measurement on wet material, a portion of the sample material was taken for reference analysis. Another portion of the remaining sample was dried at $80^{\circ} \mathrm{C}$ for $16 \mathrm{~h}$ and ground through a 1-mm sieve (Cyclotec 1093; Foss). The dried sample was measured in reflectance mode on a NIRSystems 5000 instrument (Foss) with spinning sample cup module. The wavelength range was 1100 to $2500 \mathrm{~nm}$. The measurements were performed in duplicate with repacking of the cuvette.

The samples were analyzed for $\mathrm{NH}_{3} \mathrm{~N}$, Lac, $\mathrm{HAc}, \mathrm{pH}$, EtOH, and DM. Grass silage was also analyzed for CP.

Table 2. Composition of corn silage samples used for calibration as determined by reference methods.

\begin{tabular}{|c|c|c|c|c|c|c|c|c|c|}
\hline \multirow[b]{3}{*}{ Analyte } & \multicolumn{5}{|c|}{ Number of samples ${ }^{1}$} & \multirow{2}{*}{\multicolumn{4}{|c|}{ Sample composition }} \\
\hline & & DK & $\mathrm{S}$ & DK & DK & & & & \\
\hline & Total & 2001 & 2001 & 2002 & 2003 & Mean & Minimum & Maximum & SD \\
\hline DM, \% & 227 & 179 & 10 & 16 & 22 & 30 & 22 & 43 & 3.5 \\
\hline $\mathrm{NH}_{3} \mathrm{~N}(\mathrm{DM}),{ }^{2} \%$ & 210 & 162 & 10 & 16 & 22 & 0.056 & 0.015 & 0.12 & 0.020 \\
\hline $\operatorname{Lac}(\mathrm{DM}),{ }^{2} \%$ & 202 & 154 & 10 & 16 & 22 & 5.8 & 0.23 & 11 & 1.7 \\
\hline $\mathrm{HAc}(\mathrm{DM}),{ }^{2} \%$ & 211 & 163 & 10 & 16 & 22 & 1.9 & 0.20 & 6.6 & 1.0 \\
\hline $\mathrm{pH}$ & 221 & 173 & 10 & 16 & 22 & 3.9 & 3.7 & 5.0 & 0.15 \\
\hline $\mathrm{EtOH}(\mathrm{DM}),{ }^{2} \%$ & 236 & 188 & 10 & 16 & 22 & 0.56 & 0.03 & 3.2 & 0.44 \\
\hline
\end{tabular}


Table 3. Composition of grass silage samples used for validation as determined by reference methods.

\begin{tabular}{llllcc}
\hline & \multirow{2}{*}{$\begin{array}{l}\text { Number of } \\
\text { samples }\end{array}$} & \multicolumn{4}{c}{ Sample composition } \\
\cline { 3 - 6 } Analyte & 43 & Mean & Minimum & Maximum & SD \\
\hline $\mathrm{DM}, \%$ & 43 & 40 & 22 & 79 & 14 \\
$\mathrm{NH}_{3} \mathrm{~N}(\mathrm{DM}),{ }^{1} \%$ & 43 & 0.20 & 0.10 & 0.35 & 0.066 \\
$\mathrm{Lac}(\mathrm{DM}),{ }^{1} \%$ & 43 & 2.6 & 0.08 & 12 & 3.4 \\
$\mathrm{HAc}(\mathrm{DM}),{ }^{1} \%$ & 43 & 4.6 & 0.02 & 9.6 \\
pH & 43 & 0.52 & 0.01 & 6.4 & 0.53 \\
EtOH(DM), ${ }^{1} \%$ & 43 & & & 4.0 & 0.56 \\
\hline
\end{tabular}

${ }^{1} \mathrm{NH}_{3} \mathrm{~N}$, lactic acid (Lac), acetic acid (HAc), and ethanol (EtOH) determined in wet material and expressed as a percentage of DM.

All reference analyses, except protein, were performed on wet sample material. Crude protein $\mathrm{N}$ was determined by the Dumas principle (Sweency, 1989) using a Leco CN-2000 instrument (Leco Corporation, St. Joseph, MI). Determination of $\mathrm{NH}_{3} \mathrm{~N}$ was performed by biochemical analysis (Boehringer Mannheim, Mannheim, Germany). In the presence of glutamate dehydrogenase and reduced NAD (NADH), ammonia reacts with 2-oxoglutarate, whereby NADH is reduced to NAD in a stoichiometric way. The NADH concentration was measured spectrophotometrically. Lactic acid and HAc were determined by HPLC analysis of aqueous extract using a Rezex ROA column (Phenomenex, Torrance, $\mathrm{CA}$ ), and EtOH was determined by gas chromatographic analysis of aqueous extract using a 2-m $\times 2$ mm i.d. column packed with Chromosorb 101 (JohnsManville, Denver, CO). Determination of $\mathrm{pH}$ was performed on a sample equilibrated overnight at $5^{\circ} \mathrm{C}$ with water. The DM content was determined from drying at $80^{\circ} \mathrm{C}$ for $16 \mathrm{~h}$. In all cases, 2 single determinations were performed on different days. The wet samples were kept at $-20^{\circ} \mathrm{C}$ until analysis, which was performed $2 \mathrm{~d}$ after NIR scanning.

Data were treated with WINISI version 1.04 software (Infrasoft International, Silver Spring, MD). The concentrations of Lac, $\mathrm{HAc}, \mathrm{NH}_{3} \mathrm{~N}$, and $\mathrm{EtOH}$ expressed as a percentage of $\mathrm{DM}$, but determined in wet material, were used for calibration and validation on dried materials. The concentrations in wet material were used for calibration and validation on wet materials. The $\mathrm{pH}$ values as determined in wet materials were used in both cases. Calibration was performed by partial least squares regression on full-scan mean spectra after scatter correction with the standard normal variate transformation combined with detrend. Additional pretreatment was performed by second derivative treatment. Calibration was performed using 6 cross-validation segments. One outlier elimination pass was accepted. A relatively conservative criterion based on a T-value (residual/root mean square error of cross validation [RMSECV]) of 3.0 was used. The number of partial least squares factors selected was the number giving the lowest RMSECV with the fewest factors. Calculation of reference analyte concentration in DM was performed using reference-determined DM. Predicted concentration in wet material was transformed to concentration in DM using predicted DM values. The standard error of prediction (SEP) was calculated by the following formula (Næs et al., 2002):

$$
\mathrm{SEP}=\sqrt{\frac{1}{\mathrm{~N}-1} \Sigma\left(\mathrm{x}_{\mathrm{i}}-\mathrm{y}_{\mathrm{i}}-\mathrm{bias}\right)^{2}}
$$

where $x_{i}-y_{i}=$ difference between results obtained by routine method $\left(\mathrm{x}_{\mathrm{i}}\right)$ and reference method $\left(\mathrm{y}_{\mathrm{i}}\right)$ on sample $i$.

Table 4. Composition of corn silage samples used for validation as determined by reference methods.

\begin{tabular}{|c|c|c|c|c|c|}
\hline \multirow[b]{2}{*}{ Analyte } & \multirow{2}{*}{$\begin{array}{l}\text { Number of } \\
\text { samples }\end{array}$} & \multicolumn{4}{|c|}{ Sample composition } \\
\hline & & Mean & Minimum & Maximum & SD \\
\hline $\mathrm{DM}, \%$ & 37 & 35 & 28 & 44 & 3.3 \\
\hline $\mathrm{NH}_{3} \mathrm{~N}(\mathrm{DM}),{ }^{1} \%$ & 37 & 0.054 & 0.022 & 0.13 & 0.023 \\
\hline $\operatorname{Lac}(\mathrm{DM}),{ }^{1} \%$ & 37 & 5.1 & 0.81 & 9.6 & 1.5 \\
\hline $\mathrm{HAc}(\mathrm{DM}),{ }^{1} \%$ & 37 & 1.7 & 0.91 & 4.9 & 0.79 \\
\hline $\mathrm{pH}$ & 37 & 3.8 & 3.6 & 4.3 & 0.16 \\
\hline $\operatorname{EtOH}(\mathrm{DM}),{ }^{1} \%$ & 37 & 0.89 & 0.02 & 1.5 & 0.37 \\
\hline
\end{tabular}

\footnotetext{
${ }^{1}$ Ammonia-N, lactic acid (Lac), acetic acid (HAc), and ethanol (EtOH) determined in wet material and expressed as a percentage of DM.
} 


$$
\operatorname{bias}=\frac{1}{\mathrm{~N}} \Sigma\left(\mathrm{x}_{\mathrm{i}}-\mathrm{y}_{\mathrm{i}}\right)=\overline{\mathrm{x}}-\overline{\mathrm{y}}
$$

where $\mathrm{N}=$ total number of samples in the test.

The root mean square error of prediction (RMSEP) was calculated from (Næs et al., 2002):

$$
\operatorname{RMSEP}=\sqrt{\frac{1}{\mathrm{~N}} \Sigma\left(\mathrm{x}_{\mathrm{i}}-\mathrm{y}_{\mathrm{i}}\right)^{2}} .
$$

The SEP and RMSEP were calculated from data obtained on test sets. The standard error of cross validation and the RMSECV were calculated in the same way as SEP and RMSEP but on data from cross validation (Næs et al., 2002).

The true accuracy of NIR spectroscopy was estimated from

$$
\sqrt{\mathrm{SEP}^{2}-\mathrm{SD}_{\mathrm{t}}^{2}}
$$

where $\mathrm{SD}_{\mathrm{t}}$ is the total standard deviation of the final reference results used for calibration. The $\mathrm{SD}_{\mathrm{t}}$ was calculated as the day-to-day standard deviation of the final calibration values.

The repeatability standard deviation (i.e., the variability of independent single results obtained by the same operator, using the same apparatus under the same conditions on the same test sample and in a short interval of time) and the intralaboratory reproducibility standard deviation (i.e., the variability of independent single results obtained on the same test sample in the same laboratory by different operators under different experimental conditions) were determined in accordance with ISO standard 5725-2 (International Organization for Standardization, 1994).

\section{RESULTS AND DISCUSSION}

\section{Effect of Drying Process}

Determinations of Lac, HAc, $\mathrm{NH}_{3} \mathrm{~N}$, and EtOH are normally performed on wet material. Drying at $80^{\circ} \mathrm{C}$ for $16 \mathrm{~h}$ completely evaporates volatile nonionic compounds such as EtOH. However, the effect is less clear for compounds forming salts. To investigate the drying effect on Lac, HAc, and $\mathrm{NH}_{3} \mathrm{~N}$, samples were analyzed by reference methods before and after the drying process. The possibility of predicting wet material analyses from dried material analyses was investigated for comparison with the performance obtained by NIR spectroscopy.

Lac. The results showed that the drying process has only a minor effect on the Lac concentration. The mean loss in the drying process was $3.5 \%$. The Lac determined in wet material by the reference method and expressed as a percentage of DM ( $\mathrm{Lac}(\mathrm{DM}))$ can be related to the Lac determined in dry material $\left(\mathrm{Lac}(\mathrm{DM})_{\text {dry }}\right)$ by the equations:

$$
\begin{gathered}
\operatorname{Lac}(D M)=-0.65+1.15 \times \operatorname{Lac}(D M)_{d r y} \\
r^{2}=0.96 \\
\mathrm{SD}_{\mathrm{yx}}=0.63, \mathrm{n}=125
\end{gathered}
$$

(grass silage, 2 to $13 \% \mathrm{Lac}(\mathrm{DM})$ )

$$
\begin{gathered}
\mathrm{Lac}(\mathrm{DM})=-0.24+1.09 \times \mathrm{Lac}(\mathrm{DM})_{\mathrm{dry}} \\
\mathrm{r}^{2}=0.84, \mathrm{SD}_{\mathrm{yx}}=0.53, \mathrm{n}=100 \\
(\text { corn silage }, 2 \text { to } 8 \% \operatorname{Lac}(\mathrm{DM}))
\end{gathered}
$$

Inclusion of $\mathrm{pH}$ and $\mathrm{DM}$ in the regression models did not improve the correlations.

HAc. The mean losses of HAc in the drying process were $57 \%$ for grass silage and $83 \%$ for corn silage. The acetic acid determined in wet material by the reference method and expressed as a percentage of DM $(\mathrm{HAc}(\mathrm{DM}))$ can be related to the Hac determined in dry material $\left(\mathrm{HAc}(\mathrm{DM})_{\mathrm{dry}}\right)$ by the equations:

$$
\begin{gathered}
\mathrm{HAc}(\mathrm{DM})=1.38+0.95 \times \mathrm{HAc}(\mathrm{DM})_{\mathrm{dry}} \\
\mathrm{r}^{2}=0.42, \mathrm{SD}_{\mathrm{yx}}=0.83, \mathrm{n}=100 \\
(\text { grass silage, } 0 \text { to } 10 \% \mathrm{HAc}(\mathrm{DM})) \\
\mathrm{HAc}(\mathrm{DM})=0.69+3.5 \times \mathrm{HAc}(\mathrm{DM})_{\mathrm{dry}} \\
\mathrm{r}^{2}=0.55, \mathrm{SD}_{\mathrm{yx}}=0.59, \mathrm{n}=100 \\
\quad(\text { corn silage, } 0 \text { to } 7 \% \mathrm{HAc}(\mathrm{DM}))
\end{gathered}
$$

Inclusion of $\mathrm{pH}$ and $\mathrm{DM}$ in the regression models did not improve the correlations significantly.

$\mathbf{N H}_{3} \boldsymbol{N}$. The mean losses of $\mathrm{NH}_{3} \mathrm{~N}$ in the drying process were $53 \%$ for grass silage and $16 \%$ for corn silage.

The $\mathrm{NH}_{3} \mathrm{~N}$ determined in wet material by the reference method and expressed as a percentage of $\mathrm{DM}\left(\mathrm{NH}_{3}\right.$ $\mathrm{N}(\mathrm{DM})$ ) can be related to the $\mathrm{NH}_{3} \mathrm{~N}$ determined in dry material $\left(\mathrm{NH}_{3} \mathrm{~N}(\mathrm{DM})_{\text {dry }}\right)$ by the equations:

$$
\begin{gathered}
\mathrm{NH}_{3} \mathrm{~N}(\mathrm{DM})=0.121+0.988 \times \mathrm{NH}_{3} \mathrm{~N}(\mathrm{DM})_{\mathrm{dry}} \\
\mathrm{r}^{2}=0.85, \mathrm{SD}_{\mathrm{yx}}=0.036, \mathrm{n}=40 \\
\left(\text { grass silage, } 0.04 \text { to } 0.4 \% \mathrm{NH}_{3} \mathrm{~N}(\mathrm{DM})\right) \\
\mathrm{NH}_{3} \mathrm{~N}(\mathrm{DM})=0.009+1.025 \times \mathrm{NH}_{3} \mathrm{~N}(\mathrm{DM})_{\mathrm{dry}} ; \\
\mathrm{r}^{2}=0.84, \mathrm{SD}_{\mathrm{yx}}=0.007, \mathrm{n}=40 \\
\left(\text { corn silage, } 0.02 \text { to } 0.12 \% \mathrm{NH}_{3} \mathrm{~N}(\mathrm{DM})\right)
\end{gathered}
$$

Introduction of $\mathrm{pH}$ and $\mathrm{DM}$ as variables did not improve the correlation significantly. 
Table 5. Prediction of fermentation parameters and major constituents in grass silage.

\begin{tabular}{|c|c|c|c|c|c|c|c|}
\hline Analyte & $\begin{array}{l}\mathrm{NIR}^{1} \\
\text { mode }\end{array}$ & $\begin{array}{l}\text { PLS }^{2} \\
\text { factors }\end{array}$ & $\begin{array}{l}\mathrm{T} \text { outliers } \\
\text { removed }\end{array}$ & $r^{23}$ & $\mathrm{RMSECV}^{4}$ & $\mathrm{RMSEP}^{5}$ & $\begin{array}{l}\text { SD:RMSECV } \\
\text { and } \\
\text { SD:RMSEP }\end{array}$ \\
\hline $\mathrm{NH}_{3} \mathrm{~N}(\mathrm{DM}),{ }^{7} \%$ & $\begin{array}{l}\text { Dry } \\
\text { Wet }\end{array}$ & $\begin{array}{l}10 \\
10\end{array}$ & $\begin{array}{l}2 \\
3\end{array}$ & $\begin{array}{l}0.89 \\
0.79\end{array}$ & $\begin{array}{l}0.023 \\
0.028\end{array}$ & $\begin{array}{l}0.026 \\
0.030\end{array}$ & $\begin{array}{l}3.1: 2.5 \\
2.6: 2.3\end{array}$ \\
\hline $\operatorname{Lac}(\mathrm{DM}),{ }^{7} \%$ & $\begin{array}{l}\text { Dry } \\
\text { Wet }\end{array}$ & $\begin{array}{l}15 \\
11\end{array}$ & $\begin{array}{l}1 \\
5\end{array}$ & $\begin{array}{l}0.96 \\
0.93\end{array}$ & $\begin{array}{l}0.71 \\
0.84\end{array}$ & $\begin{array}{l}0.54 \\
0.64\end{array}$ & $\begin{array}{l}4.9: 6.3 \\
4.2: 5.3\end{array}$ \\
\hline $\mathrm{HAc}(\mathrm{DM}), \mathrm{d}^{7} \%$ & $\begin{array}{l}\text { Dry } \\
\text { Wet }\end{array}$ & $\begin{array}{l}10 \\
10\end{array}$ & $\begin{array}{l}2 \\
5\end{array}$ & $\begin{array}{l}0.68 \\
0.74\end{array}$ & $\begin{array}{l}0.97 \\
0.91\end{array}$ & $\begin{array}{l}0.65 \\
0.57\end{array}$ & $\begin{array}{l}2.0: 2.5 \\
2.1: 2.8\end{array}$ \\
\hline $\mathrm{pH}$ & $\begin{array}{l}\text { Dry } \\
\text { Wet }\end{array}$ & $\begin{array}{l}11 \\
15\end{array}$ & $\begin{array}{l}5 \\
7\end{array}$ & $\begin{array}{l}0.92 \\
0.91\end{array}$ & $\begin{array}{l}0.11 \\
0.13\end{array}$ & $\begin{array}{l}0.11 \\
0.15\end{array}$ & $\begin{array}{l}3.7: 4.8 \\
3.2: 3.5\end{array}$ \\
\hline $\operatorname{EtOH}(\mathrm{DM}),{ }^{7} \%$ & Wet & 10 & 4 & 0.89 & 0.22 & 0.20 & $3.3: 2.8$ \\
\hline DM, \% & Wet & 6 & 6 & 0.99 & 0.89 & 1.05 & $16: 13$ \\
\hline $\mathrm{CP}(\mathrm{DM}),{ }^{8} \%$ & $\begin{array}{l}\text { Dry } \\
\text { Wet }\end{array}$ & $\begin{array}{l}13 \\
13\end{array}$ & $\begin{array}{l}0 \\
6\end{array}$ & $\begin{array}{l}0.97 \\
0.93\end{array}$ & $\begin{array}{l}0.48 \\
0.78\end{array}$ & & $\begin{array}{l}5.8 \\
3.6\end{array}$ \\
\hline
\end{tabular}

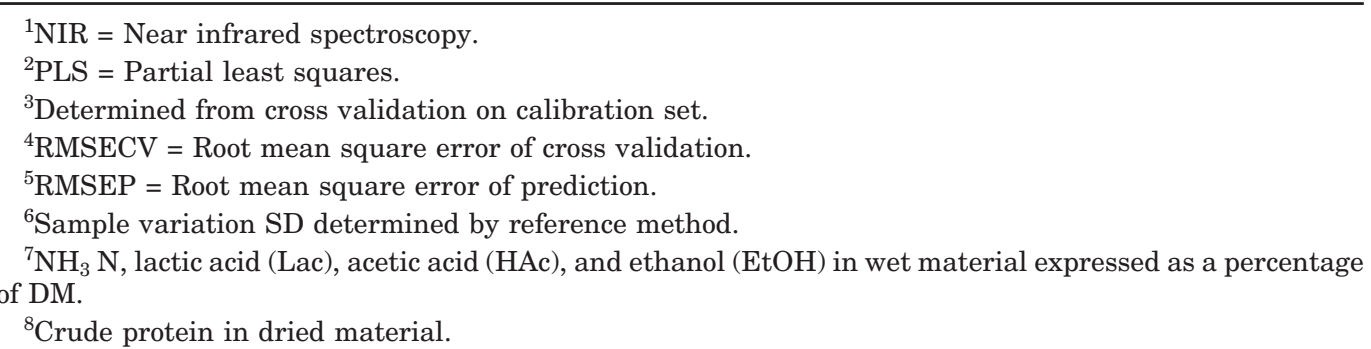

\section{NIR Predictions}

Lac. Prediction of Lac was more accurate on dried sample material than wet material (Tables 5 and 6). The RMSECV values obtained by cross validation were $0.71 \%$ for grass silage and $0.36 \%$ for corn silage when measured on dried material. The predictive capability of NIR spectroscopy is illustrated in Figure 1. The standard deviation:RMSECV for dried material were 4.9 on grass silage and 4.7 on corn silage. A lower limit of 2.0 is often used in assessment of the applicability of NIR spectroscopy for forage analyses. The corresponding ra-

Table 6. Prediction of fermentation parameters and major constituents in corn silage.

\begin{tabular}{|c|c|c|c|c|c|c|c|}
\hline Analyte & $\begin{array}{l}\mathrm{NIR}^{1} \\
\text { mode }\end{array}$ & $\begin{array}{l}\mathrm{PLS}^{2} \\
\text { factors }\end{array}$ & $\begin{array}{l}\mathrm{T} \text { outliers } \\
\text { removed }\end{array}$ & $r^{23}$ & $\mathrm{RMSECV}^{4}$ & RMSEP $^{5}$ & $\begin{array}{l}\text { SD:RMSECV } \\
\text { and } \\
\text { SD:RMSEP }\end{array}$ \\
\hline $\mathrm{NH}_{3} \mathrm{~N}(\mathrm{DM}),{ }^{7} \%$ & $\begin{array}{l}\text { Dry } \\
\text { Wet }\end{array}$ & $\begin{array}{l}9 \\
9\end{array}$ & $\begin{array}{l}2 \\
1\end{array}$ & $\begin{array}{l}0.77 \\
0.72\end{array}$ & $\begin{array}{l}0.007 \\
0.008\end{array}$ & $\begin{array}{l}0.008 \\
0.009\end{array}$ & $\begin{array}{l}2.9: 2.9 \\
2.5: 2.6\end{array}$ \\
\hline $\operatorname{Lac}(\mathrm{DM}),{ }^{7} \%$ & $\begin{array}{l}\text { Dry } \\
\text { Wet }\end{array}$ & $\begin{array}{l}10 \\
12\end{array}$ & $\begin{array}{l}3 \\
3\end{array}$ & $\begin{array}{l}0.95 \\
0.91\end{array}$ & $\begin{array}{l}0.36 \\
0.47\end{array}$ & $\begin{array}{l}0.39 \\
0.48\end{array}$ & $\begin{array}{l}4.7: 3.8 \\
3.6: 3.1\end{array}$ \\
\hline $\mathrm{HAc}(\mathrm{DM}),{ }^{7} \%$ & $\begin{array}{l}\text { Dry } \\
\text { Wet }\end{array}$ & $\begin{array}{l}10 \\
10\end{array}$ & $\begin{array}{l}2 \\
1\end{array}$ & $\begin{array}{l}0.72 \\
0.84\end{array}$ & $\begin{array}{l}0.52 \\
0.41\end{array}$ & $\begin{array}{l}0.40 \\
0.39\end{array}$ & $\begin{array}{l}1.9: 2.0 \\
2.4: 2.0\end{array}$ \\
\hline $\mathrm{pH}$ & $\begin{array}{l}\text { Dry } \\
\text { Wet }\end{array}$ & $\begin{array}{l}9 \\
9\end{array}$ & $\begin{array}{l}2 \\
3\end{array}$ & $\begin{array}{l}0.78 \\
0.62\end{array}$ & $\begin{array}{l}0.063 \\
0.080\end{array}$ & $\begin{array}{l}0.074 \\
0.087\end{array}$ & $\begin{array}{l}2.4: 2.2 \\
1.9: 1.8\end{array}$ \\
\hline $\operatorname{EtOH}(\mathrm{DM}),{ }^{7} \%$ & Wet & 12 & 1 & 0.92 & 0.11 & 0.10 & $4.0: 3.7$ \\
\hline $\mathrm{DM}, \%$ & Wet & 6 & 1 & 0.93 & 0.97 & 1.1 & $3.6: 3.0$ \\
\hline
\end{tabular}




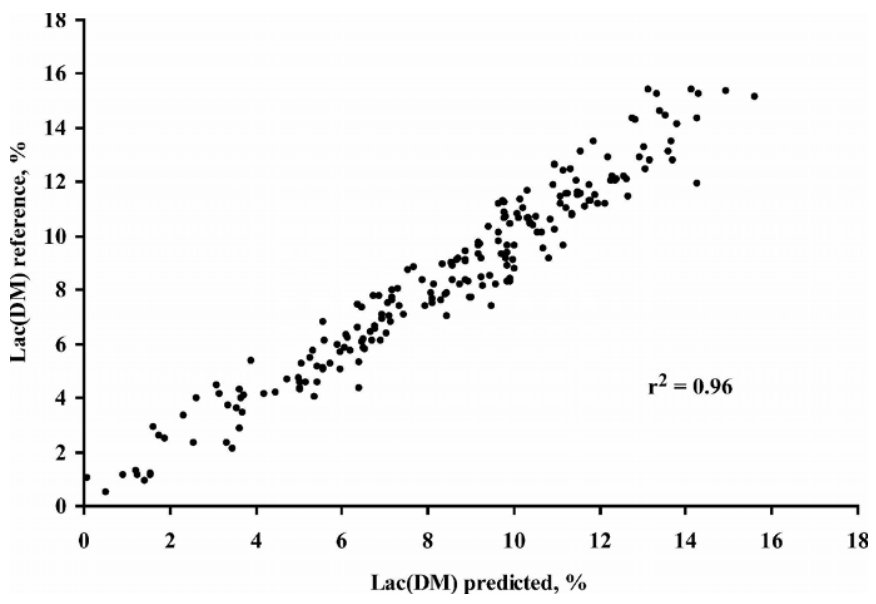

Figure 1. Correlation between Lac(DM) (lactic acid determined in wet material and presented as a percentage of DM) as predicted by near infrared (NIR) spectroscopy and Lac(DM) determined by the reference method in grass silage. The results were obtained by cross validation on the calibration set. The NIR measurements were performed on dried sample material.

tios for wet material were 4.2 and 3.6. The RMSECV and RMSEP values for dried corn silage appeared to be underestimated because the intralaboratory reproducibility standard deviation was on the same level (Table 7). The true accuracy of NIR spectroscopy for dried material was estimated as $0.29 \%$.

An improvement in predictive capability from calibration on Lac determined in dry material rather than Lac determined in wet material by the reference method and expressed as a percentage of DM followed by calculations using Equations [1] and [2] could not be obtained because 1) the loss of Lac during the drying process was very low and 2) the conversion from Lac determined in dry material to Lac determined in wet material values was not characterized by an standard deviation significantly lower than the RMSECV.

The 400- to 1100-nm spectral range did not contribute significantly to the prediction accuracy on wet material. Furthermore, the accuracy could not be improved by

Table 7. Intralaboratory reproducibility standard deviations $\left(\mathrm{SD}_{\mathrm{R}, \text { intra }}\right)$ of single determinations performed by reference methods.

\begin{tabular}{lll}
\hline & \multicolumn{2}{c}{$\mathrm{SD}_{\mathrm{R}, \text { intra }}$} \\
\cline { 2 - 3 } Analyte & $\begin{array}{l}\text { Grass } \\
\text { silage }\end{array}$ & $\begin{array}{l}\text { Corn } \\
\text { silage }\end{array}$ \\
\hline $\mathrm{NH}_{3} \mathrm{~N}(\mathrm{DM}),{ }^{1} \%$ & 0.013 & 0.006 \\
$\mathrm{Lac}(\mathrm{DM}),{ }^{1} \%$ & 0.40 & 0.35 \\
$\mathrm{HAc}(\mathrm{DM}),{ }^{1} \%$ & 0.25 & 0.14 \\
$\mathrm{pH}$ & 0.035 & 0.017 \\
$\mathrm{EtOH}(\mathrm{DM}),{ }^{1} \%$ & 0.070 & 0.058 \\
\hline
\end{tabular}

${ }^{1} \mathrm{NH}_{3} \mathrm{~N}$, lactic acid (Lac), acetic acid (HAc), and ethanol (EtOH) determined in wet material and expressed as a percentage of DM.

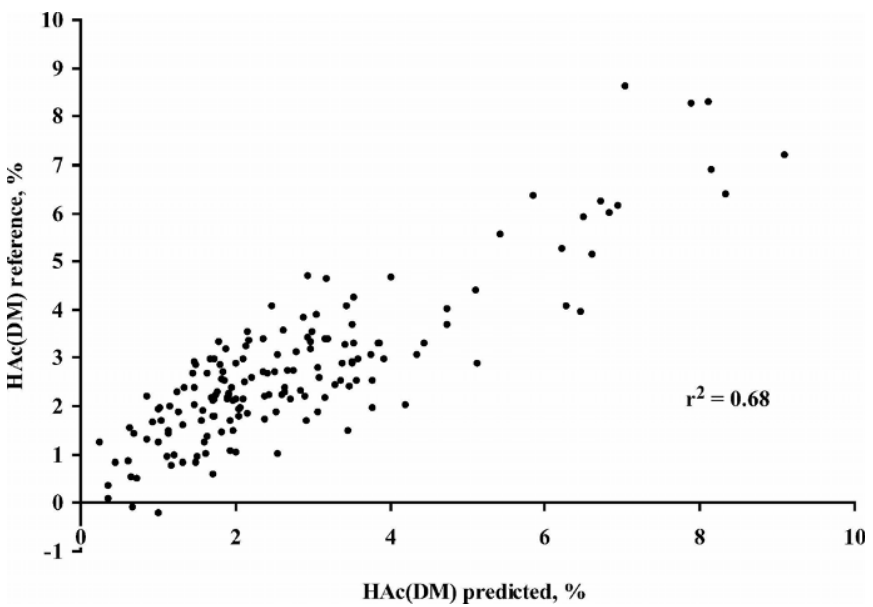

Figure 2. Correlation between HAc(DM) (acetic acid determined in wet material and presented as a percentage of DM) predicted by near infrared (NIR) spectroscopy and HAc(DM) determined by the reference method in grass silage. The results were obtained by cross validation on the calibration set. The NIR measurements were performed on dried sample material.

trimming the wavelength range to single or multiple segments showing highest correlation to Lac. The same observations were made for the other parameters calibrated.

HAc. Because most of the HAc was evaporated during the drying process, it was not expected that a good relationship between spectral data of dried samples and the HAc content in original samples would be found. This was verified by standard deviation:RMSECV of 2.0 and 1.9 for grass silage and corn silage, respectively. The predictive capability of NIR spectroscopy is illustrated in Figure 2. The high standard deviation of Equations [3] and [4] excluded the possibility of obtaining a significantly better prediction of HAc from NIR analysis of dried sample material using a calibration developed on the results for Hac determined in dry material followed by a conversion of the results using Equations [3] and [4].

Calibration on wet materials only improved the accuracy slightly. The standard deviation:RMSECV values were 2.1 and 2.4 for grass silage and corn silage, respectively.

The results show that it is difficult to extract spectral information for HAc determination. The nearly identical standard deviation:RMSECV obtained from measurements on dried grass silage and dried corn silagealthough much more HAc is evaporated during the drying process in the case of corn silage-could indicate that the calibration does not measure HAc directly, but merely measures properties correlated with HAc. This conclusion is supported by results obtained from calibration on residual HAc in dried material. These cali- 


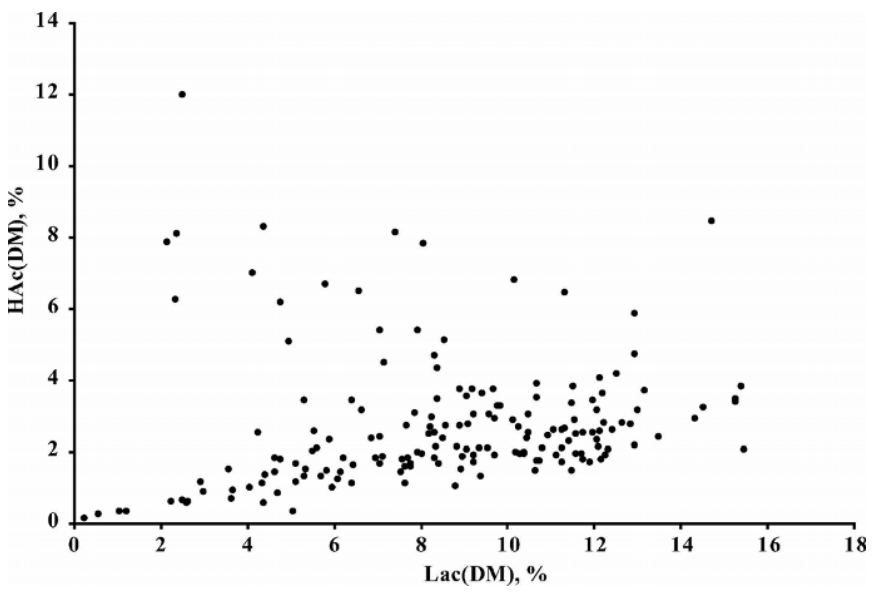

Figure 3. Correlation between Lac(DM) (lactic acid determined in wet material and presented as a percentage of $\mathrm{DM})$ and $\mathrm{HAc}(\mathrm{DM})$ (acetic acid determined in wet material and presented as a percentage of DM) in calibration samples of grass silage as determined by reference methods.

brations still gave standard deviation:RMSECV at the 2.0 level. The possibility that the HAc calibration solely reflects spectral data for Lac can be rejected because many of the calibration samples showed outlying features with respect to the Lac:HAc (Figures 3 and 4). The correlation plots for Lac and HAc showed similarities but also some differences in certain wavelength regions (Figures 5 and 6), which also indicates that the HAc and Lac calibration models do not extract exactly the same properties from spectral data.

Grass silage $\boldsymbol{p H}$. Prediction of $\mathrm{pH}$ was better on dried material than on wet material (Table 5). The

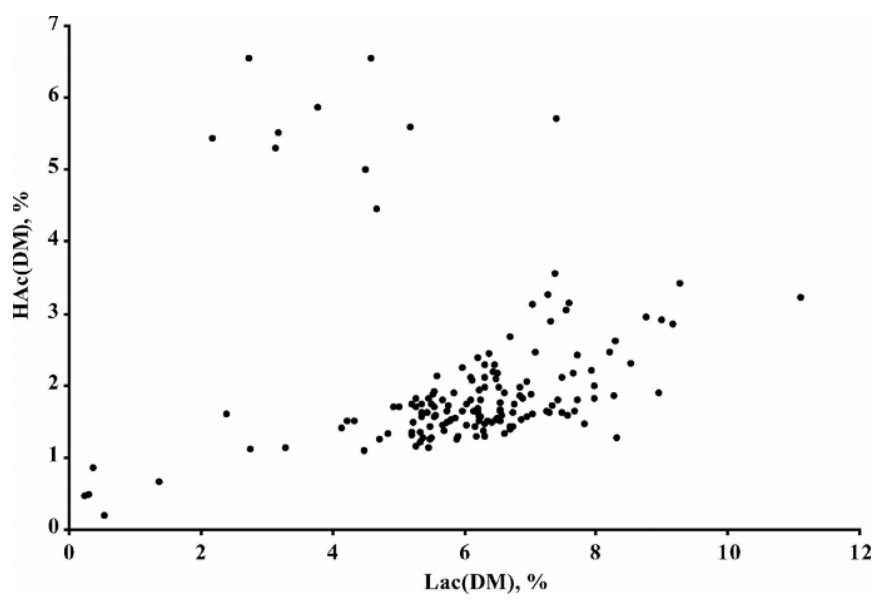

Figure 4. Correlation between Lac(DM) (lactic acid determined in wet material and presented as a percentage of DM) and $\mathrm{HAc}(\mathrm{DM})$ (acetic acid determined in wet material and presented as a percentage of DM) in calibration samples of corn silage as determined by reference methods.

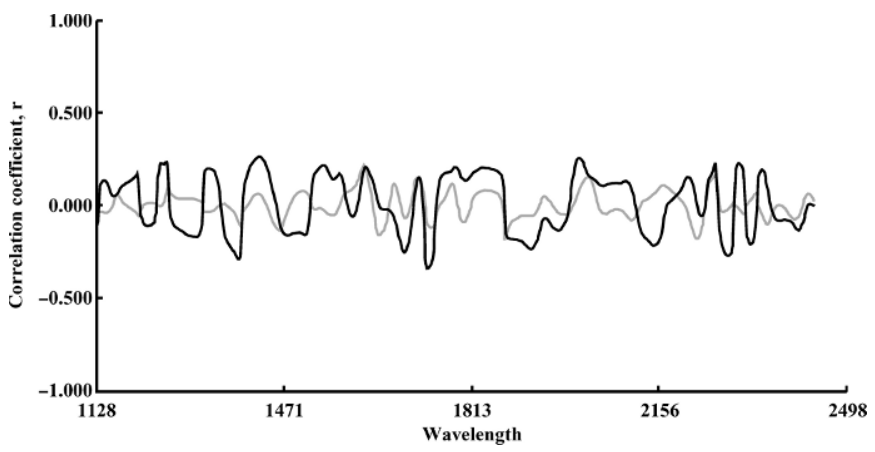

Figure 5. Correlation plots showing the correlation between near infrared spectral data and Lac(DM) (lactic acid determined in wet material and presented as a percentage of DM) (bright curve) and $\mathrm{HAc}(\mathrm{DM})$ (acetic acid determined in wet material and presented as a percentage of DM) (dark curve) in dried grass silage. Spectra were pretreated by standard normal variate transformation and second derivative treatment.

RMSECV values obtained were 0.11 for dried material and 0.13 for wet material. The corresponding standard deviation:RMSECV for dried and wet materials were 3.7 and 3.2. The accuracy of NIR spectroscopy is illustrated in Figure 7.

The correlation between $\mathrm{pH}$ and Lac, Hac, and DM was investigated on calibration samples using reference data. The correlation can be expressed by the equations:

$$
\begin{gathered}
\mathrm{pH}=5.28-1.17 \\
\times \log (\operatorname{Lac}(\mathrm{DM})) ; \mathrm{r}^{2}=0.74, \mathrm{SD}_{\mathrm{yx}}=0.18 \text { and } \\
\mathrm{pH}=4.21-1.19 \times \log (\mathrm{Lac})+0.014 \\
\times \mathrm{DM} ; \mathrm{r}^{2}=0.76, \mathrm{SD}_{\mathrm{yx}}=0.18
\end{gathered}
$$

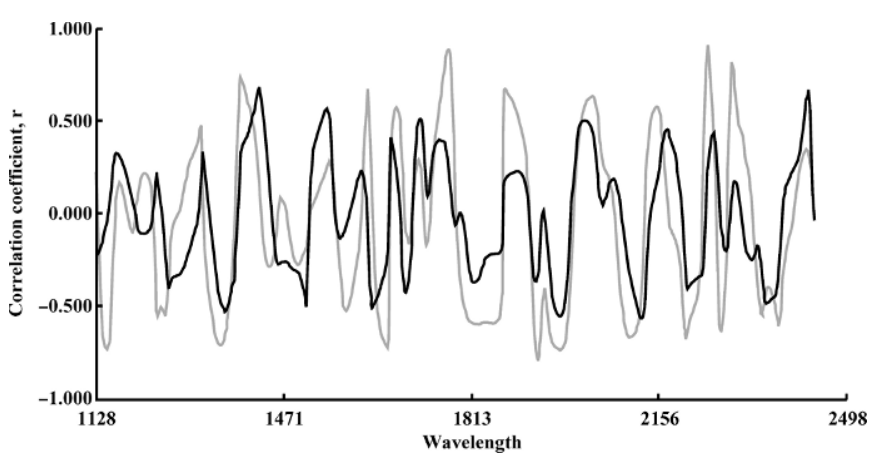

Figure 6. Correlation plots showing the correlation between near infrared spectral data and $\mathrm{Lac}(\mathrm{DM})$ (lactic acid determined in wet material and presented as a percentage of DM) (bright curve) and $\mathrm{HAc}(\mathrm{DM})$ (acetic acid determined in wet material and presented as a percentage of DM) (dark curve) in dried corn silage. Spectra were pretreated by standard normal variate transformation and second derivative treatment. 


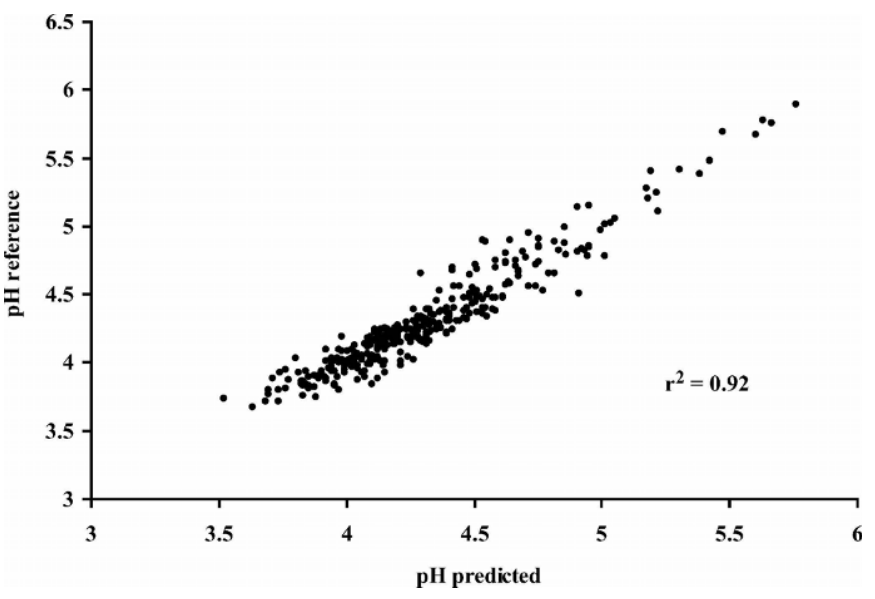

Figure 7. Correlation between $\mathrm{pH}$ predicted by near infrared (NIR) spectroscopy and $\mathrm{pH}$ determined by the reference method in grass silage. The results were obtained by cross validation on the calibration set. The NIR measurements were performed on dried sample material.

Inclusion of HAc(DM) and DM as factors in Equation [7] and HAc as a factor in Equation [8] did not improve the standard deviation of regression.

The high $\mathrm{SD}_{\mathrm{yx}}$ values compared with the RMSECV values of 0.11 to 0.13 indicate that the $\mathrm{pH}$ calibration equation was not related merely to the contents of the major acids and DM.

Corn silage $\boldsymbol{p H}$. The $\mathrm{pH}$ of corn silage could be predicted with RMSECV values of 0.06 and 0.08 for dried and wet materials (Table 6). The standard devia-

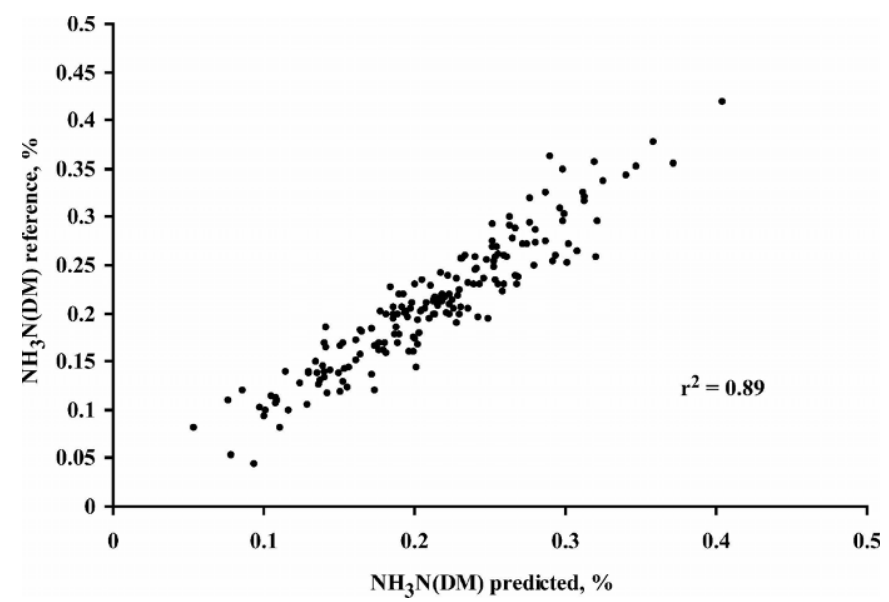

Figure 8. Correlation between $\mathrm{NH}_{3} \mathrm{~N}(\mathrm{DM})\left(\mathrm{NH}_{3} \mathrm{~N}\right.$ determined in wet material and presented as a percentage of DM) predicted by near infrared (NIR) spectroscopy and $\mathrm{NH}_{3} \mathrm{~N}(\mathrm{DM})$ determined by the reference method in grass silage. The results were obtained by cross validation on the calibration set. The NIR measurements were performed on dried sample material.

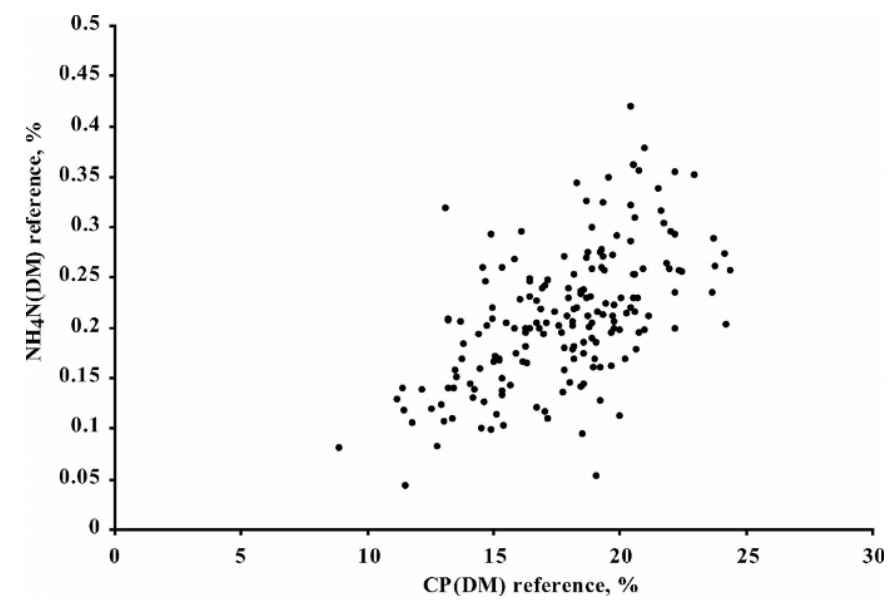

Figure 9. Correlation between $\mathrm{CP}$ and $\mathrm{NH}_{4} \mathrm{~N}$ concentrations (percentage of DM) as determined by reference methods in grass silage.

tion:RMSECV for dried and wet materials were 2.4 and 1.9 , respectively.

The correlation between $\mathrm{pH}$ and Lac, Hac, and DM could be expressed by the equations:

$$
\begin{gathered}
\mathrm{pH}=4.65-1.02 \\
\times \log (\operatorname{Lac}(\mathrm{DM})) ; \mathrm{r}^{2}=0.79, \mathrm{SD}_{\mathrm{yx}}=0.076 \text { and } \\
\mathrm{pH}=3.95-1.00 \times \log (\mathrm{Lac})+0.005 \\
\times \mathrm{DM} ; \mathrm{r}^{2}=0.83, \mathrm{SD}_{\mathrm{yx}}=0.051 .
\end{gathered}
$$

Because the SEP values related to $\log (\operatorname{Lac}(\mathrm{DM}))$ and $\log (\mathrm{Lac})$ were 0.040 and 0.045 , respectively, regression

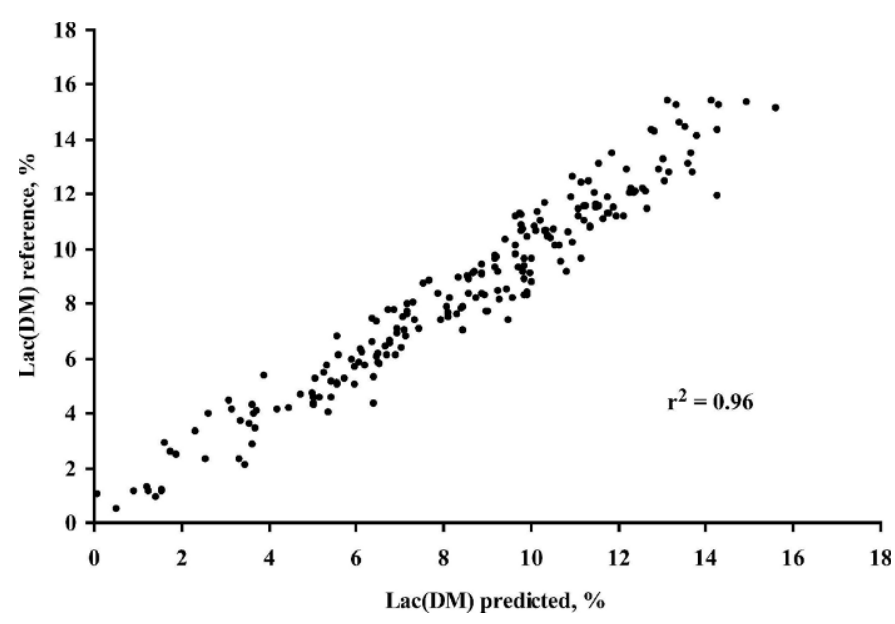

Figure 10. Correlation between ethanol $(\mathrm{EtOH})$ predicted by near infrared (NIR) spectroscopy and EtOH determined by the reference method in grass silage (percentage of DM). The results were obtained by cross validation on the calibration set. The NIR measurements were performed on wet sample material. 
Table 8. Repeatability standard deviation of NIR analyses $\left(\mathrm{SD}_{\mathrm{r}, \mathrm{NIR}}\right)$ including uncertainty from re-packing of sampling cells.

\begin{tabular}{llllll}
\hline & \multicolumn{2}{c}{$\begin{array}{c}\text { Calibration performed on } \\
\text { dry material }\end{array}$} & & \multicolumn{2}{c}{$\begin{array}{c}\text { Calibration performed on } \\
\text { wet material }\end{array}$} \\
\cline { 2 - 2 } Analyte & Grass silage & Corn silage & & Grass silage & Corn silage \\
\hline $\mathrm{NH}_{3} \mathrm{~N}(\mathrm{DM}){ }^{1} \%$ & 0.004 & 0.002 & & 0.018 & 0.007 \\
$\mathrm{Lac}(\mathrm{DM}),{ }^{1} \%$ & 0.14 & 0.12 & & 0.31 & 0.34 \\
$\mathrm{HAc}(\mathrm{DM}),{ }^{1} \%$ & 0.11 & 0.15 & & 0.26 & 0.33 \\
$\mathrm{pH}$ & 0.021 & 0.034 & & 0.062 & 0.039 \\
$\mathrm{EtOH}(\mathrm{DM}),{ }^{1} \%$ & & & 0.081 & 0.092 \\
$\mathrm{DM}, \%$ & 0.18 & & 0.79 & 1.1 \\
$\mathrm{CP}(\mathrm{DM}),{ }^{2} \%$ & & & 0.69 & \\
\hline
\end{tabular}

${ }^{1} \mathrm{NH}_{3} \mathrm{~N}$, lactic acid (Lac), acetic acid (HAc), and ethanol (EtOH) in wet material expressed as a percentage of DM.

${ }^{2}$ Crude protein in dried material.

models 9 and 10 indicate that the $\mathrm{pH}$ calibration equation for corn silage may reflect the Lac content.

$\mathbf{N H}_{3} \mathbf{N}$. Prediction of $\mathrm{NH}_{3} \mathrm{~N}$ was slightly more accurate on dried sample material compared with wet material (Tables 5 and 6). The RMSECV values for dried material were $0.023 \%$ (grass silage) and $0.007 \%$ (corn silage). The standard deviation:RMSECV for dried material were 3.1 on grass silage and 2.9 on corn silage. The accuracy of NIR spectroscopy is illustrated in Figure 8 . The corresponding ratios for wet material were 2.6 and 2.5 , respectively.

As illustrated in Figure 9, the $\mathrm{NH}_{3} \mathrm{~N}$ content could not be predicted simply from the protein content. Inclusion of the $\mathrm{pH}$ in a regression model did not improve the predictability. However, the possibility that other fermentation properties may correlate with the $\mathrm{NH}_{3} \mathrm{~N}$ content, and thereby contribute to the calibration model, cannot be excluded.

Because the standard deviations for conversion of $\mathrm{NH}_{3} \mathrm{~N}$ determined in dry material to $\mathrm{NH}_{3} \mathrm{~N}$ determined in wet material were on the same level as or higher than the RMSECV and RMSEP values, it was not possible to obtain a better accuracy by calibration on values for $\mathrm{NH}_{3} \mathrm{~N}$ determined in dry material followed by conver-

Table 9. Standard error of cross validation corrected for the repeatability error of NIR measurements.

\begin{tabular}{llc}
\hline Analyte & $\begin{array}{l}\text { Grass silage } \\
\text { (dry/wet) }\end{array}$ & $\begin{array}{l}\text { Corn silage } \\
\text { (dry/wet) }\end{array}$ \\
\hline $\mathrm{NH}_{3} \mathrm{~N}(\mathrm{DM}){ }^{1} \%$ & $0.023 / 0.025$ & $0.007 / 0.007$ \\
$\mathrm{Lac}(\mathrm{DM}){ }^{1} \%$ & $0.70 / 0.81$ & $0.35 / 0.42$ \\
$\mathrm{HAc}(\mathrm{DM}),{ }^{1} \%$ & $0.97 / 0.89$ & $0.51 / 0.34$ \\
$\mathrm{pH}$ & $0.11 / 0.12$ & -060.08 \\
$\mathrm{EtOH},{ }^{1} \%$ & $-/ 0.21$ & -10.09 \\
$\mathrm{CP}(\mathrm{DM}),{ }^{2} \%$ & $0.46 / 0.61$ & \\
\hline
\end{tabular}

${ }^{1} \mathrm{NH}_{3} \mathrm{~N}$, lactic acid (Lac), acetic acid (HAc), and ethanol (EtOH) in wet material expressed as a percentage of DM.

${ }^{2}$ Crude protein in dried material. sion to values for $\mathrm{NH}_{4} \mathrm{~N}$ determined in dry material values using Equations [5] and [6].

$\boldsymbol{E t O H}$. The organic solvent EtOH is evaporated during the drying process because of its volatility and nonionic nature. Thus, it is thus impossible to determine EtOH directly in the dried material by reference methods. An attempt to build a calibration model on dried material also showed that there were no indirect relationships between the original EtOH content and NIR spectral data of dried samples.

The EtOH content could be determined in wet silage with a standard deviation:RMSECV of at least 3 , which indicates that NIR spectroscopy is suitable for determination of EtOH in silage (Tables 5 and 6; Figure 10).

\section{Repeatability of NIR Measurements}

The repeatability uncertainty of NIR measurements $\left(\mathbf{S D}_{\mathbf{r}, \mathbf{N I R}}\right)$ was insignificant compared with the prediction error when measurements were performed on dried material (Table 8). The $\mathrm{SD}_{\mathrm{r}, \mathrm{NIR}}$ was considerably higher when measurements were performed on wet material, but still low compared with RMSECV and RMSEP values. If the SECV values were corrected for $\mathrm{SD}_{\mathrm{r}, \mathrm{NIR}}$, then the differences between the accuracy obtained on dried and wet materials were reduced slightly for $\mathrm{NH}_{3} \mathrm{~N}$, Lac, and pH (Table 9). For protein, a $30 \%$ difference in uncertainty remained after correction.

\section{CONCLUSIONS}

The results showed that NIR spectroscopy can be useful in the prediction of Lac, $\mathrm{pH}, \mathrm{NH}_{3} \mathrm{~N}$, and EtOH in grass and corn silage. The technique is less accurate for HAc, but may be used to obtain a rough estimate of the concentration level. For compounds that are not affected by the drying process, the accuracy of NIR was significantly better when measurements were per- 
formed on dried material compared with wet material. This was clearly demonstrated by the parameters Lac and protein. The difference could only partly be explained by differences in repeatability errors of NIR measurements. For $\mathrm{NH}_{3} \mathrm{~N}$, which is moderately affected by the drying process, the slightly higher uncertainty on wet material could mainly be explained by the repeatability error of NIR measurements. For Hac, which is highly affected by the drying process, the accuracy was better on wet material, even before correction for imprecision.

\section{REFERENCES}

International Organization for Standardization. 1994. Standard 5725-2, ISO, Accuracy (Trueness and Precision) of Measurement Methods and Results. Part 2: Basic Method for the Determination of Repeatability and Reproducibility of a Standard Measurement Method. Int. Org. Standardization, Geneva, Switzerland.

Næs, T., T. Isaksson, T. Fearn, and T. Davies. 2002. A User-Friendly Guide to Multivariate Calibration and Classification. NIR Publications, Chichester, United Kingdom.

Park, R. S., R. E. Agnew, and R. J. Barnes. 1999. The development of near infrared reflectance spectroscopy calibrations for undried grass silage and their transfer to another instrument using multi- ple and single sample standardisation. J. Near Infrared Spectrosc. 7:117-131.

Park, R. S., R. E. Agnew, F. J. Gordon, and R. W. J. Steen. 1998. The use of near infrared reflectance spectroscopy (NIRS) on undried samples of grass silage to predict chemical composition and digestibility parameters. Anim. Feed Sci. Technol. 72:155-167.

Park, R. S., R. E. Agnew, and D. J. Kilpatrick. 2002. The effect of freezing and thawing on grass silage quality predictions based on near infrared reflectance spectroscopy. Anim. Feed Sci. Technol. 102:151-167.

Randby, Å. T., I. Selmer-Olsen, and L. Baevre. 1998. Effect of ethanol in feed on milk flavor and chemical composition. J. Dairy Sci. 82:420-428.

Reeves, J. B., III, T. H. Blosser, and V. F. Colenbrander. 1989. Near infrared reflectance spectroscopy for analysing undried silage. J. Dairy Sci. 72:79-88.

Rook, A. J., and M. Gill. 1990. Prediction of the voluntary intake of grass silages by beef cattle. Anim. Prod. 50:425-438.

Sinnaeve, G., P. Dardenne, R. Agneessens, and R. Biston. 1994. The use of near infrared spectroscopy for the analysis of fresh grass silage. J. Near Infrared Spectrosc. 2:79-84.

Snyman, L. D., and H. W. Joubert. 1992. Near-infrared reflectance analysis of the fermentation characteristics of silage prepared by chemical treatment to prevent volatilization of fermentation end products. Anim. Feed Sci. Technol. 37:47-58.

Steen, R. W. J., F. J. Gordon, L. E. R. Dawson, R. S. Park, C. S. Mayne, R. E. Agnew, D. J. Kilpatrick, and M. G. Porter. 1998. Factors affecting the intake of grass silage by cattle and prediction of silage intake. Anim. Sci. 66:115-127.

Sweency, R. A. 1989. Generic combustion method for determination of crude protein in feeds: Collaborative study. J. AOAC 72:770-774. 